\title{
Pemodelan Pertumbuhan Lahan Terbangun sebagai Upaya Prediksi Perubahan Lahan Pertanian di Kabupaten Karanganyar
}

\author{
Rivan Aji Wahyu Dyan Syafitri dan Cahyono Susetyo \\ Departemen Perencanaan Wilayah dan Kota, Fakultas Arsitektur Desain dan Perencanan, \\ Institut Teknologi Sepuluh Nopember (ITS) \\ e-mail: cahyono_s@urplan.its.ac.id
}

\begin{abstract}
Abstrak-Perubahan lahan pertanian telah menjadi fenomena akan dampak dari perkembangan penduduk. Di Kabupaten Karanganyar hingga tahun 2016 pertumbuhan penduduk mencapai $0,9 \%$ per tahun. Secara fisik konversi lahan pertanian yang terjadi dipengaruhi olah adanya perkembangan industri dan permukiman, dilalui jalan nasional dan dampak sprawl dari Kota Surakarta. Hal tersebut mengakibatkan tingginya perkembangan lahan terbangun sementara luas lahan yang tersedia relatif tetap. Menimbangan dari perubahan lahan yang terus berkembang maka diperlukan pemodelan spasial perubahan lahan berbasis prediksi guna meminimalisir dampak pada masa yang akan datang. Sehingga dalam penelitian ini akan membahas pemodelan pertumbuhan lahan terbangun sebagai upaya prediksi perubahan lahan pertanian di Kabupaten Karanganyar. Melalui teknik AHP (Analytical Hierarchy Process) dapat diketahui variabel yang berpengaruh terhadap alih fungsi lahan pertanian. Kemudian ditransformasi melalui simulasi dengan pendekatan Cellular Automata dapat diketahui prediksi perubahan lahan pertanian. Hasil penelitian menunjukkan prediksi perubahan lahan pertanian di Kabupaten Karanganyar hingga tahun 2038 seluas 2369.69 Ha, dengan pola pertumbuhan lahan terbangun yang cenderung pada kawasan perkotaan Kabupaten Karanganyar.
\end{abstract}

Kata Kunci-Cellular Automata, Lahan Pertanian, Prediksi Lahan.

\section{PENDAHULUAN}

$\mathrm{K}$ ABUPATEN Karanganyar termasuk dalam wilayah pengembangan strategis pertumbuhan ekonomi Subosukawonosraten, dengan fungsi sebagai penunjang pengembangan kegiatan Industri, Pertanian dan Pariwisata. Dalam RTRW diterangkan Kabupaten Karanganyar sebagai "Bumi INTANPARI", dimana sektor unggulannya meliputi Industri, Pertanian dan Pariwisata. Sehingga sektor pertanian merupakan salah satu aspek yang perlu diperhatikan di Kabupaten Karanganyar. Permasalahan utama sektor pertanian yang dihadapi saat ini adalah alih fungsi lahan pertanian [1]. Hal tersebut erat kaitannya terhadap pertumbuhan penduduk yang sangat pesat, dimana berimplikasi pada tingginya kebutuhan lahan terbangun. Pasalnya laju pertumbuhan penduduk di Kabupaten Karanganyar tahun 2016 mencapai $0,9 \%$ per tahun, sementara luas lahan yang tersedia relatif tidak bertambah [2]. Ditinjau dari kondisi fisik dan lingkungannya alih fungsi lahan pertanian yang terjadi dikarenakan pengaruh adanya perkembangan industri dan permukiman, sedangkan dari sisi perekonomian adalah permasalahan kecenderungan PDRB yang rendah [3]. Kabupaten Karanganyar tak lepas dari adanya dampak urban sprawl sebagai kawasan hinterland Kota Surakarta [4]. Keadaan demikian akan berpengaruh terhadap penurunan daya dukung lahan dan lingkungan. Hal itu terlihat dari semakin meningkatnya laju besaran degradasi, alih fungsi dan fragmentasi lahan pertanian dari tahun ke tahun [5] Alih fungsi lahan pertanian di Kabupaten Karanganyar dari tahun 2007 sampai tahun 2017 mencapai $\pm 1523,26$ ha atau setara 152 ha/tahun. Pada tahun 2007 total luas lahan pertanian pangan di Karanganyar sebesar 41437.60 ha, namun pada tahun 2017 luas lahan pertanian di Indonesia hanya sebesar 39914.33 ha. Disisi lain dari tahun 2007-2017 sektor perumahan dan industri menagalami peningkatan seluas 448,66 Ha [2]. Sehingga alternatif yang diberlakukan adalah perumusan LP2B (Lahan Pertanian Pangan Berkelanjutan) guna menjawab swasembada pangan [6]. Namun, dikarenakan belum adanya payung hukum terkait alokasi LP2B di Kabupaten Karanganyar sehingga masih banyak alih fungsi lahan pertanian yang terjadi.

Menimbangan dari perubahan lahan yang terus berkembang maka diperlukan pemodelan spasial perubahan lahan berbasis prediksi, dengan tujuan untuk meminimalisir intervensi dampak pertumbuhan lahan terhadap lahan pertanian. Dalam hal ini teknik analisis yang digunakan adalah cellular automata dan Geographic Information System (GIS) guna mengetahui lahan pertanian mana yang kedepannya akan terkoversi maupun sebaliknya. Cellular Automata (CA) sebagai salah satu pendekatan pemodelan perubahan lahan telah menjadi teknik yang sering digunakan sebagai mekanisme untuk eksplorasi, estimasi, dan prediksi terhadap fenomena perkembangan lahan [7]. Dalam menghadapi era global yang kian pesat simulasi menggunakan teknologi sangat diperlukan dalam menghadapi perkembangan yang ada. Salah satunya adalah software LanduseSim, yang merupakan software berbasis pendekatan Celluar Automata.

\section{METODE PENELITIAN}

\section{A. Metode Pengumpulan Data}

Pengumpulan data yang digunakan dalam penelitian ini adalah metode pengumpulan data primer dan sekunder. Metode pengumpulan data primer dilakukan dengan pengamatan secara langsung (survei lapangan), wawancara dan kuesioner. Metode pengumpulan data sekunder diperoleh dari instansi maupun data literatur yang diarsipkan (Tabel 1). 
Tabel 1.

Teknik Pengumpulan Data

\begin{tabular}{|c|c|c|c|}
\hline No & Data & Sumber Data & Teknik/Sumber \\
\hline 1 & $\begin{array}{c}\text { Kondisi pemanfaatan } \\
\text { lahan di } \\
\text { Kab.Karanganyar }\end{array}$ & $\begin{array}{c}\text { Wilayah } \\
\text { penelitian }\end{array}$ & Observasi \\
\hline 2 & $\begin{array}{l}\text { Faktor-faktor pengaruh } \\
\text { pertumbuhan lahan } \\
\text { terbangun }\end{array}$ & $\begin{array}{l}\text { Pemerintah, } \\
\text { Masyarakat }\end{array}$ & $\begin{array}{l}\text { Wawancara, } \\
\text { Kuesioner }\end{array}$ \\
\hline 3 & $\begin{array}{l}\text { Peta penggunaan lahan } \\
\text { Kab. Karanganyar } \\
\text { tahun } 2007\end{array}$ & $\begin{array}{c}\text { RTRW } \\
\text { Kabupaten } \\
\text { Karangayar } \\
\text { 2008-2029 }\end{array}$ & $\begin{array}{c}\text { Baperlitbang dan } \\
\text { Dinas PU Cipta Karya } \\
\text { Kabupaten } \\
\text { Karanganyar }\end{array}$ \\
\hline 4 & $\begin{array}{l}\text { Peta penggunaan lahan } \\
\text { Kab.Karanganyar } \\
\text { tahun } 2017\end{array}$ & $\begin{array}{c}\text { Citra Quicbird } \\
2017\end{array}$ & Observasi \\
\hline
\end{tabular}

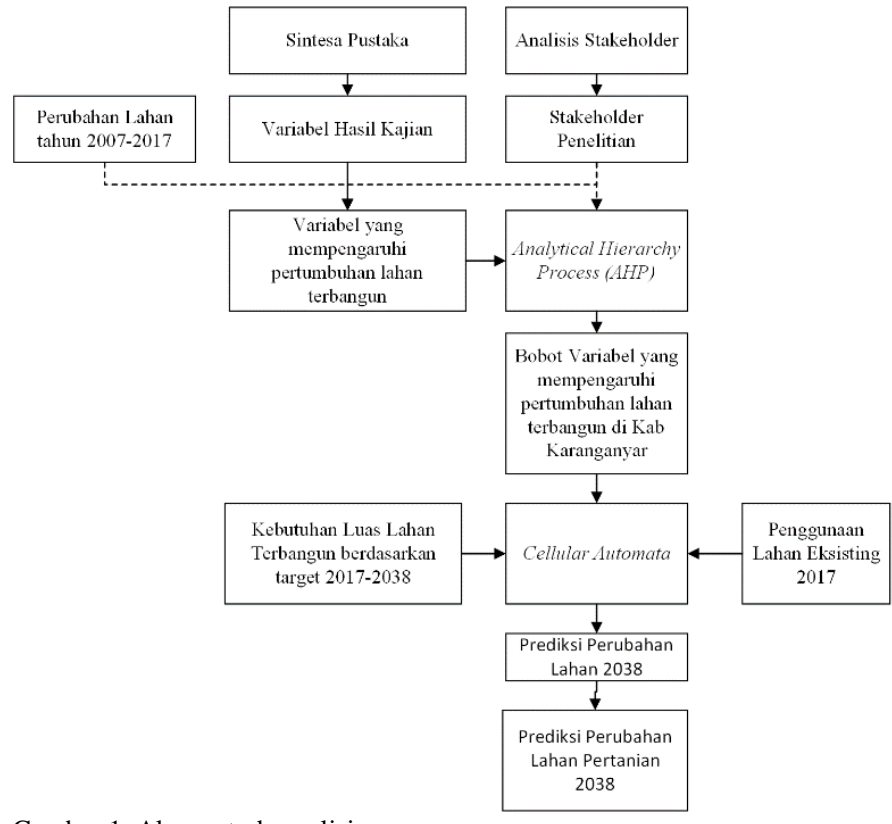

Gambar 1. Alur metode analisis.

\section{B. Metode Analisis}

Metode analisis yang digunakan dalam penelitian ini dapat dilihat pada Gambar 1.

1. Identifikasi karakteristik perubahan lahan tahun 2007-2017

Identifikasi karakteristik perubahan lahan dilakukan melalui overlay dengan tujuan mendapatkan matrik perubahan lahan serta karakteristik alih fungsi lahan yang terjadi di Kabupaten Karanganyar. Sehingga dapat diamati secara spasial variabel yang mempengaruhi pertumbuhan lahan terbangun (Gambar 2).

2. Analisis Stakeholder

Populasi dalam penelitian ini adalah seluruh stakeholder's yang memiliki kepentingan kaitannya dalam perubahan lahan pertanian. Stakeholder yang dimaksud antara lain:

1. Pihak Pemerintah

2. Pihak Masyarakat

3. Pihak Akademisi

Sampel dalam penelitian ini dilakukan dengan menggunakan teknik non probability sampling. Non probability sampling adalah Pemilihan sampel dengan cara ini tidak menghiraukan prinsip-prinsip probability yaitu tidak memberi peluang/kesempatan yang sama bagi setiap unsur atau anggota populasi untuk dipilih menjadi sampel. Teknik dalam pengambilan stakeholder menggunakan teknik purposive sampling [8]. Teknik purposive sampling merupakan teknik penentuan sampel dengan pertimbangan khusus sehingga layak dijadikan sampel. Pemilihan sekelompok subjek dalam purposive sampling didasarkan atas ciri-ciri tertentu yang dipandang mempunyai pengaruh dan kepentingan yang erat dengan ciri-ciri populasi.

3. Merumuskan variabel yang mempengaruhi pertumbuhan lahan terbangun

Identifikasi variabel-variabel yang mempengaruhi pertumbuhan lahan terbangung diperoleh dari kajian teori kemudian disimpulkan berdasarkan pemahaman dari peneliti dan disesuaikan dengan kondisi yang terdapat di lokasi penelitian. Setelah variabel-variabel ditentukan, selanjutnya adalah mengkonfirmasi variabel-variabel tersebut kepada stakeholder terpilih sekaligus diberikan skor besar pengaruhnya terhadap penentuan kawasan pertanian berkelanjutan. Analisis perhitungan variabel-variabel tersebut menggunakan Analitycal Hierarchy Process (AHP). AHP merupakan suatu model pendukung keputusan yang dikembangkan oleh Thomas L. Saaty. Model pendukung keputusan ini akan menguraikan masalah multi faktor atau multi kriteria yang kompleks menjadi suatu hirarki [9]. Proses AHP dilakukan menggunakan Software Expert Choice.

4. Memodelkan Perubahan lahan tahun 2038 dalam upaya prediksi perubahan lahan pertanian

Pemodelan perubahan lahan dilakukan dengan mensimulasikan pertumbuhan lahan terbangun menggunakan Celluar Automata pada LanduseSim. Dikarenakan pola perubahan penggunaan lahan yang paling spesifik pertumbuhannya adalah lahan terbangun [10]. Celluar Automata (CA) secara konseptual dapat dipahami sebagai pendekatan "berbasis sel" untuk memodelkan gaya grafivasi dinamis pada tingkat mikro [11]. CA merupakan teknik yang paling tepat dan efisien untuk pemodelan dinamika penggunaan lahan [7]. Kaitannya terhadap pemodelan, cellular automata didasari pada driving factor dalam merumuskan aturan transisi [12].

LanduseSim sendiri merupakan software (perangkat lunak) spatial planning model mampu memberikan kontrol dan solusi kepada perencana untuk mendapatkan informasi Land Use Change (perubahan penggunaan lahan) di masa yang akan datang akibat dari suatu alternatif perencanaan. LanduseSim merupakan software simulasi dan pemodelan spasial berbasis grid/cell dengan menggunakan data raster penggunaan lahan sebagai atribut spasial. Pemodelan dan simulasi berbagis grid telah terbukti memiliki beberapa keuntungan, yaitu: entitas geografis dan karakteristik perilaku individu/obyek dalam lingkup mikro-spatial dilibatkan, model berorientasi obyek dan dapat menyatukan spatial topologi, ekspresi terintegrasi di dalam maupun diluar ruangan dapat direalisasikan, dan mampu menerapkan model simulasi kerumunan. LanduseSim didesain dan dikembangkan untuk kebutuhan perencanaan dimana perencana memiliki kemampuan untuk menentukan faktorfaktor spasial yang digunakan untuk memprediksi masa depan dengan pendekatan perencanaan [13]. Sehingga penggunaan LanduseSim dengan pendekatan Cellular Automata merupakan salah satu metode yang tepat dalam melakukan pemodelan prediksi perubahan lahan dengan faktor-faktor yang telah ditentukan. 


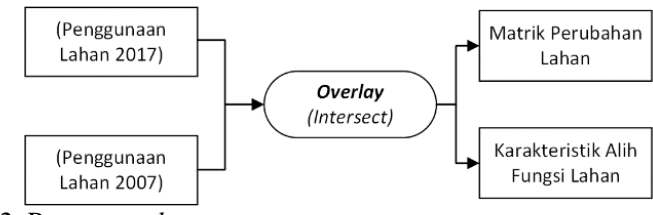

Gambar 2. Proses overlay.

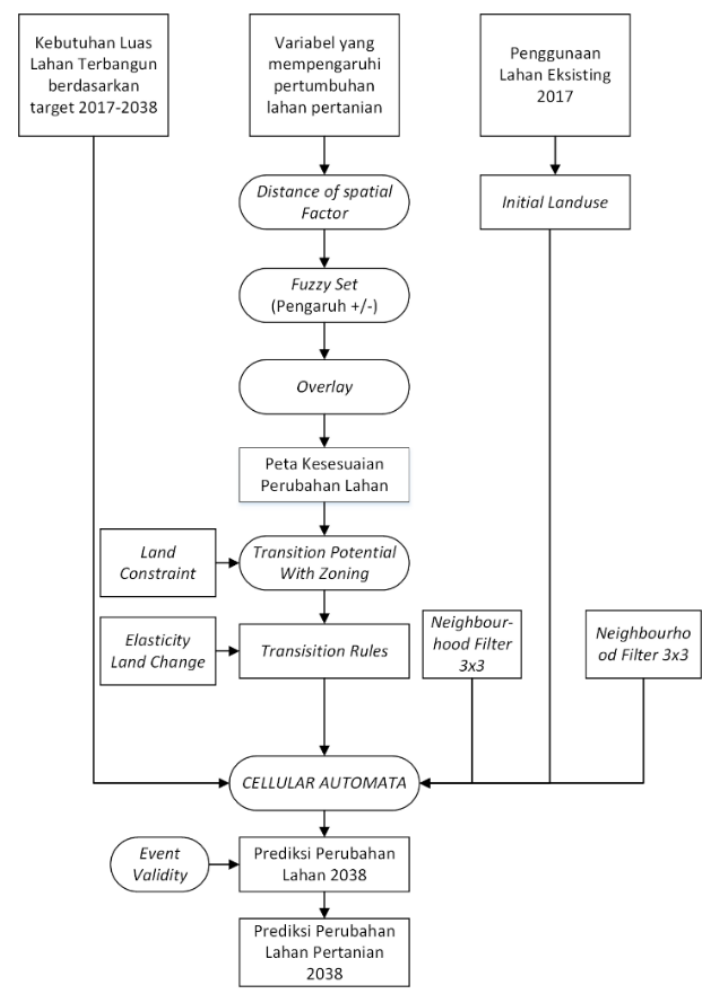

Gambar 3. Alur metode analisis.

Tabel 2.

Perubahan Lahan 2007-2017

\begin{tabular}{clr}
\hline \hline No & Jenis Penggunaan Lahan & Luas (Ha) \\
\hline 1 & HL & -0.71 \\
2 & HP & -0.32 \\
3 & KSA/KPA & -0.13 \\
4 & Lahan Terbangun & 1524.99 \\
5 & Perkebunan/Kebun & -174.91 \\
6 & Sawah & -819.84 \\
7 & Sawah Tadah Hujan & -24.18 \\
8 & Semak Belukar & -48.74 \\
9 & Sungai & 0.00 \\
10 & Tegalan/Ladang & -456.15 \\
11 & Waduk & 0.00 \\
& Jumlah & 0 \\
\hline \hline
\end{tabular}

Tabel 3.

Matrik Perubahan Lahan 2007-2017

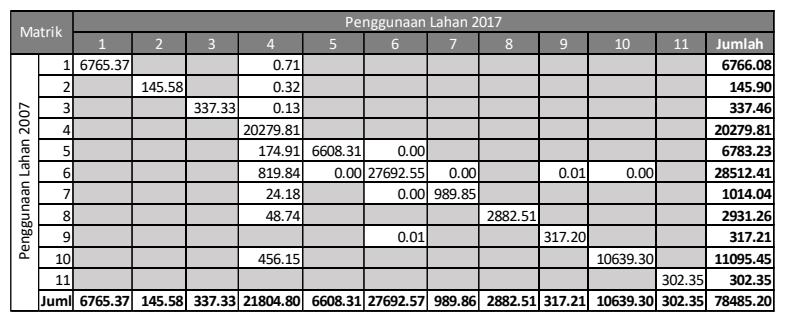

Ket: (1):Hutan Lindung, (2):Hutan Produksi, (3):Kawasan Suaka Alam, (4):Lahan Terbangun, (5):Perkebunan/kebun, (6):Sawah, (7):Sawah Tadah Hujan, (8):Semak Belukar, (9): Sungai, (10):Tegalan/ladang,, (11): Waduk.
Rentang waktu dalam memprediksi pertumbuhan lahan terbangun pada Kabupaten Karanganyar hingga tahun 2038. Dengan tujuan mengikuti pertimbangan kegiatan perencanaan Kabupaten Karanganyar dalam penyusunan RTRW tahun 2018-2038. sehingga dilakukan prediksi selama 21 tahun. Tahapan untuk memodelkan perubahan lahan dapat dilihat pada Gambar 3.

\section{HASIL DAN PEMBAHASAN}

\section{A. Identifikasi karakteristik perubahan lahan tahun 2007- 2017}

Mengidentifikasi karakteristik perubahan lahan di Kabupaten Karanganyar menggunakan data penggunaan lahan tahun 2007 yang diperoleh dari RT RW Kabupaten Karanganyar tahun 2008-2029 dan data penggunaan lahan tahun 2017 yang diperoleh dari Citra Quickbird dengan perbesaran $0,68 \mathrm{~m} \mathrm{x}$ 0,68m. Klasifikasi penggunaan lahan tahun 2017 merupakan hasil dari digitation on screen pada Citra Quickbird dengan GIS yang kemudian dilakukan validasi lapangan. Proses digitation dilakukan pada ukuran skala paling optimal yaitu 1:5000 dengan pertimbangan ukuran piksel maksimal dari citra Quickbird yang digunakan [14]. Klasifikasi jenis penggunaan lahan 2017 mengacu pada Pedoman Kriteria Teknis Kawasan Budidaya dan Permen No 16/PRT/M/2009 tentang pedoman penyusunan RTRW Kabupaten yang kemudian disesuaikan dengan ketersediaan penggunaan lahan di wilayah penelitian dan pembagian berdasarkan RTRW Kabupaten Karanganyar. Adapun tahapan analisis sebagai berikut:

1. Merumuskan matrik perubahan lahan

Matrik perubahan lahan diperoleh dari hasil overlay intersect dengan GIS pada penggunaan lahan tahun 2007 dengan penggunaan lahan tahun 2017. Identifikasi variabel penyebab pertumbuhan lahan terbangun dilakukan dalam selang timeseries (deret berkala) 10 tahun selain agar mendapatkan keakuratan data perubahan lahan tapi juga mendapatkan perubahan yang cukup signifikan [15]. Hasil dari overlay terjadi pertumbuhan lahan terbangun seluas $1524 \mathrm{Ha}$ dan penurunan pada penggunaan lahan lain seperti lahan sawah dan perkebunan (Tabel 2 dan 3).

2. Identifikasi Karakteristik Perubahan Lahan

Terdapat alih fungsi/perubahan lahan akibat pengaruh pertumbuhan lahan terbangun di Kabupaten Karanganyar selama tahun 2007-2017 yang cenderung ke arah perkotaan. Alih fungsi lahan yang terjadi paling tinggi cenderung mengkonversi lahan pertanian, dikarenakan pembangunan kegiatan non pertanian seperti kompleks perumahan, pertokoan, perkantoran, dan kawasan industri lebih mudah dilakukan pada tanah sawah dibandingkan dengan tanah kering. Sehingga dalam upaya prediksi perubahan lahan pertanian di Kabupaten Karanganyar diperlukan simulasi pada pertumbuhan lahan terbangun dengan pendekatan Cellular Automata. (Gambar 4).

\section{B. Analisis Stakeholder}

Hasil dari tahap ini diperoleh stakeholder yang memiliki kepentingan dan pengaruh yang erat terhadap pertumbuhan lahan terbangun khususnya yang menyebabkan perubahan lahan pertanian (Tabel 4). 


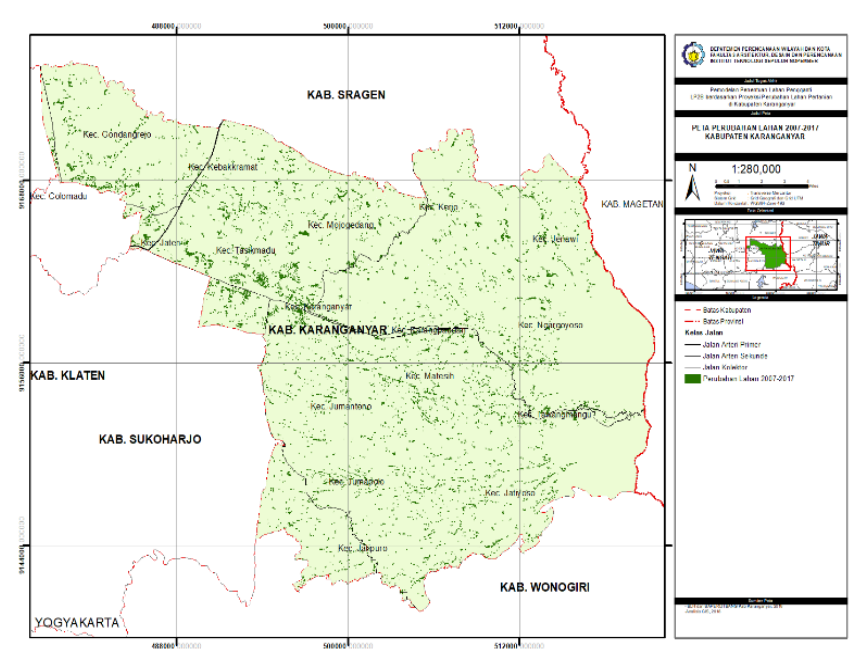

Gambar 4. Peta perubahan lahan 2007-2017.

Tabel 4.

Daftar nama stakeholder

\begin{tabular}{|c|c|c|c|}
\hline No & $\begin{array}{l}\text { Pihak } \\
\text { stakeholder }\end{array}$ & Stakeholder & Nama Stakeholder \\
\hline \multirow[t]{9}{*}{1} & \multirow[t]{9}{*}{ Pemerintah } & Kementrian Pertanian RI & $\begin{array}{l}\text { Paulus B.K. Santoso } \\
\text { Drs, MSi }\end{array}$ \\
\hline & & Dinas Pertanian & \multirow{4}{*}{$\begin{array}{l}\text { Muhammad } \\
\text { Surahman S.T. } \\
\text { Suhartono S.T. }\end{array}$} \\
\hline & & Kab.Karanganyar & \\
\hline & & BLH dan & \\
\hline & & BAPPERLITBANG & \\
\hline & & Kab.Karanganyar & \\
\hline & & DPU Cipta Karya & \multirow[t]{2}{*}{ Supani ST. M.Si. } \\
\hline & & Kab.Karanganyar & \\
\hline & & $\begin{array}{l}\text { BP4K (Badan Pengawas dan } \\
\text { Penyuluh Pertanian Pangan) }\end{array}$ & \multirow[t]{2}{*}{ Paiman S.T. } \\
\hline 2 & Masyarakat & $\begin{array}{l}\text { Kabupaten Karanganyar } \\
\text { Gapoktan (Kelompok Tani) }\end{array}$ & \\
\hline \multirow[t]{2}{*}{3} & \multirow[t]{2}{*}{ Akademisi } & Ahli Perkembangan Kota & $\begin{array}{l}\text { Putu Gede Ariastita } \\
\text { ST.MT. }\end{array}$ \\
\hline & & Ahli Perkembangan Wilayah & $\begin{array}{l}\text { Winny } \\
\text { ST.MT. }\end{array}$ \\
\hline
\end{tabular}

C. Merumuskan variabel yang mempengaruhi pertumbuhan lahan terbangun

Untuk memperoleh variabel yang mempengaruhi pertumbuhan lahan terbangun tersebut dilakukan kajian pustaka yang dengan hasil dapat dilihat pada Tabel 5.

Dari hasil sintesa tersebut dilakukan peninjauan terhadap perubahan lahan yang terjadi dikabupaten karanganyar dan dilakukan validasi kepada stakeholder untuk memperoleh variable yang memiliki pengaruh di Kabupaten Karanganyar beserta proses pembobotan. Setelah itu dilakukan proses validasi data dengan melakukan pemeriksaan nilai inkonsistensi pada hasil perhitungan. Setelah diketahui nilai inkonsistensinya kurang dari 0.1 maka dilakukan proses kombinasi. Proses kombinasi ini dilakukan untuk mengetahui bobot setiap variable dari perhitungan bobot masing-masing stakeholder. Adapun variabel yang berpengaruh dan kombinasi pembobotan dari stakeholder tersebut menggunakan Analytical Hierachy Process (AHP) ditunjukkan pada Gambar 5.

D. Memodelkan Perubahan lahan tahun 2038 dalam upaya prediksi perubahan lahan pertanian Kabupaten Karanganyar

Mensintesa dari Pratomoatmojo (2012) [6] tahapan dalam pemodelan berbabis Cellular Automata Sebagai berikut:
Tabel 5.

Kajian Teori pengaruh Pertumbuhan lahan terbnagun

\begin{tabular}{|c|c|c|}
\hline No & Pakar & Variabel \\
\hline 1 & $\begin{array}{l}\text { Bramley, et al., } 2014 \\
\text { [16] }\end{array}$ & $\begin{array}{l}\text { sosial ekonomi } \\
\text { faktor batasan dan potensi biofisik, } \\
\text { karakteristik ketetanggaan (neighbourhood), } \\
\text { faktor kebijakan institusional }\end{array}$ \\
\hline 2 & $\begin{array}{lr}\text { Saefulhakim } & \& \\
\text { Nasoetion., } & 1995 . \\
{[17]} & \end{array}$ & $\begin{array}{l}\text { Pembangunan kegiatan non pertanian } \\
\text { (perumahan, pertokoan, perkantoran, dan } \\
\text { kawasan industri) } \\
\text { infrastruktur ekonomi } \\
\text { Faktor sosial dan perekenomian petani }\end{array}$ \\
\hline 3 & $\begin{array}{l}\text { Nasution dan } \\
\text { Winoto, 1996. [18] }\end{array}$ & $\begin{array}{l}\text { sektor pertanian } \\
\text { sektor pembuatan } \\
\text { sektor perumahan } \\
\text { sektor pariwisata. }\end{array}$ \\
\hline 4 & $\begin{array}{l}\text { Rahardian (2015) } \\
\text { [19] variabel } \\
\text { pertumbuhan lahan } \\
\text { permukiman }\end{array}$ & $\begin{array}{l}\text { Harga lahan kawasan } \\
\text { Ketinggian lahan kawasan } \\
\text { Tingkat kelerengan lahan } \\
\text { Tingkat kerentanan tanah } \\
\text { Menjauhi daerah potensi rawan bencana alam } \\
\text { Menjauhi lokasi aktivitas industri } \\
\text { Mendekati pusat perdagangan kawasan } \\
\text { Terlayani fasilitas pendidikan } \\
\text { Terlayani fasilitas kesehatan } \\
\text { Terlayani fasilitas perkantoran } \\
\text { Terlayani fasilitas perbankan } \\
\text { Terlayani fasilitas peribadatan } \\
\text { Mendekati Interchange Jalan TOL } \\
\text { Memiliki jaringan listrik } \\
\text { Memiliki jaringan air bersih } \\
\text { Mendekati Jalan Arteri } \\
\text { Mengikuti Jalan Lingkungan yang ada } \\
\text { Menjauhi jaringan Jalan Kereta Api } \\
\text { Menjauhi jaringan sungai } \\
\text { Kondisi keamanan lingkungan } \\
\text { Kemudahan perizinan pendirian rumah }\end{array}$ \\
\hline
\end{tabular}

Sumber: Hasil Studi Literatur, 2018

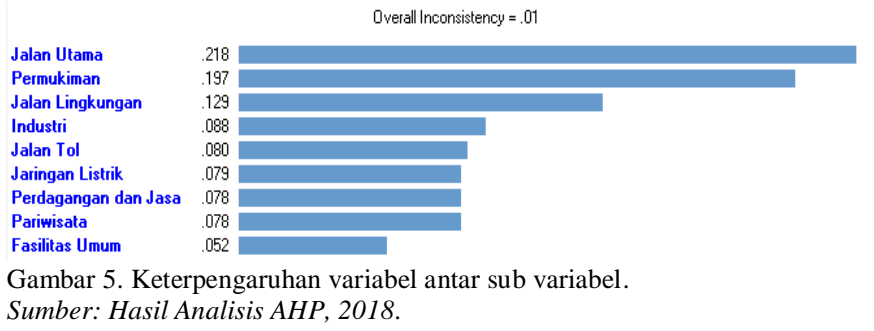

1. Menentukan kebutuhan lahan terbangun (Cell Growth)

Analisis ini bertujuan untuk menentukan prediksi besar kebutuhan luas lahan terbangun di Kabupaten Karanganyar. Kebutuhan lahan terbangun dilihat berdasarkan target permukiman dan industri dari RTRW Kabupaten Karanganyar. Perhitungan target mengacu pada pedoman Permenperin Nomor 35 Tahun 2010, Permen Perumahan Rakyat RI Nomor 10 Tahun 2012, RP4D Kabupaten (Keputusan Menteri Negara Perkim Nomor 09/KPTS/M/IX/1999), dan SNI 03-1733-2004 Tentang Tata Cara Perencanaan Lingkungan Perumahan di Perkotaan (Tabel 6).

2. Menentukan ukuran Cell dalam raster

Besar ukuran cell yang digunakan adalah $30 \mathrm{~m} \times 30 \mathrm{~m}=$ $900 \mathrm{~m}^{2}$. Ukuran cell sebesar 30x30 dipilih berdasarkan keterediaan ukuran cell maksimal dari data SRTM (Shuttle Radar Topography Missio) [20]. 


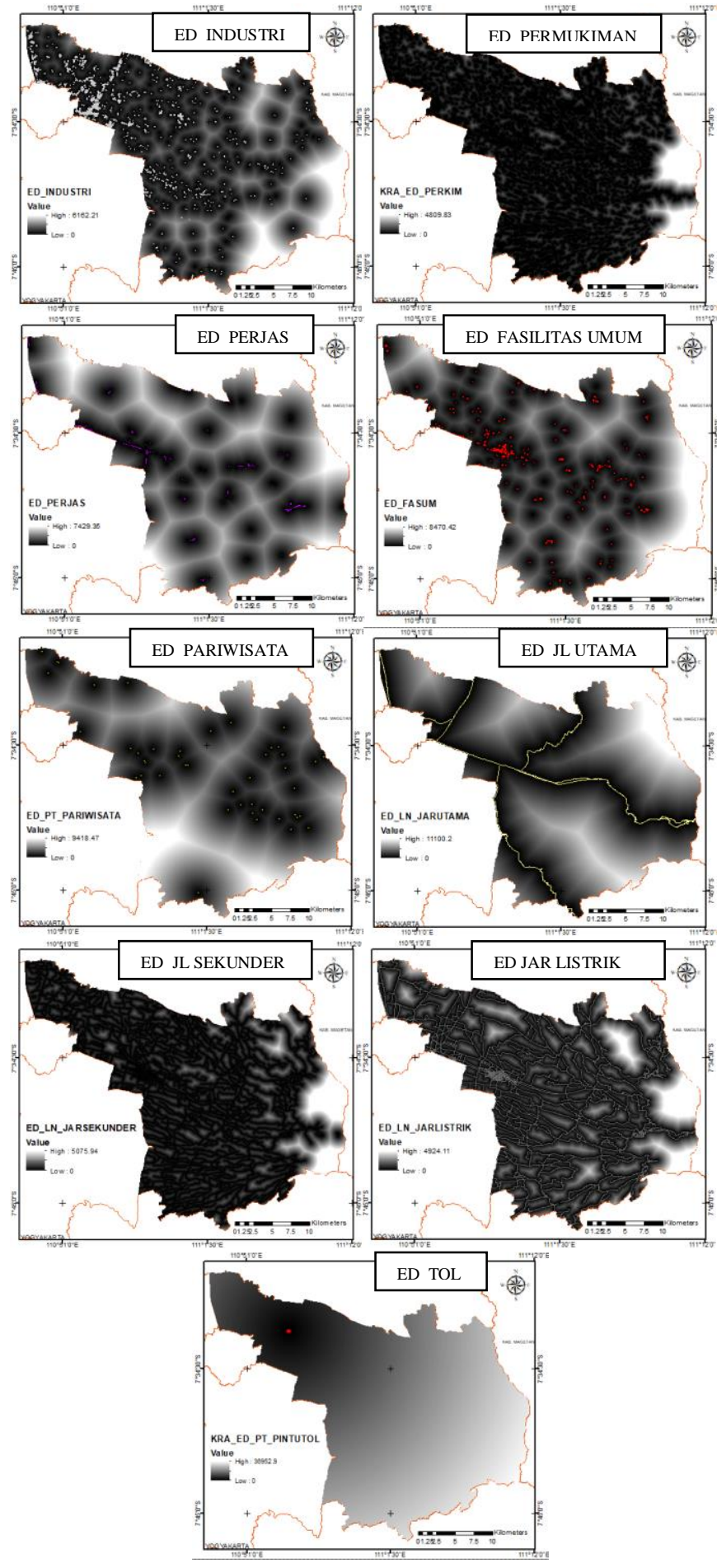

Gambar 6. Peta daerah keterjangkauan variable.

Sumber: Hasil analisis Eucludean Distance, 2018

3. Membuat daerah jangkauan variabel pertumbuhan lahan terbangun

Membuat daerah jangkauan dilakukan melalui analisis berbasis jarak (Euclidean distane) atau dalam toolbox LanduseSim 2.3.1 berupa distance of spatial faktor. Hal ini dikarenakan masing-masing faktor berpengaruh yang terpilih tersebut bersifat luas dan menempel terhadap wilayah penelitian, yang menunjukan bahwa semakin mendekati nilai 0 tersebut maka lahan semakin cepat tumbuh (Gambar 6).
Tabel 6.

Analisis perhitungan kebutuhan lahan 2017-2038 Kabupaten Karanganyar

\begin{tabular}{lccc}
\hline \multicolumn{1}{c}{ Target Kebutahan } & Kebutuhan & Target 2038 & Cellsize \\
& Lahan & & \\
& Terbangun & & \\
& $2017-2032$ & & \\
\hline Industri 78,92 Ha & $1750,36 \mathrm{Ha}$ & Diasumsikan & 27228 cell \\
Permukiman Buruh & & pertumbuhan statis & \\
Industri 74,74 Ha & & maka 1750,36 Ha/15 & \\
Permukiman & & (jumlah tahun)*21 & \\
Penduduk & & (tahun prediksi) & \\
$1596,7 \mathrm{Ha}$ & & $=2450,504 \mathrm{Ha}$ & \\
\hline \hline
\end{tabular}

Tabel 7.

Zona Constraint Kabupaten Karanganyar

\begin{tabular}{|c|c|c|c|}
\hline No & $\begin{array}{l}\text { Nama Zona } \\
\text { Constraint }\end{array}$ & Regulasi & Alokasi Luas Constraint \\
\hline 1 & $\begin{array}{l}\text { Sempadan } \\
\text { mata air }\end{array}$ & $\begin{array}{l}\text { RTRW Kab Karanganyar } \\
2008-2029 \text {, Perda No.10 } \\
\text { th } 2012 \text { tentang } \\
\text { perlindungan mata air } \\
\text { (200 m dari tepi muka air } \\
\text { tertinggi) }\end{array}$ & \\
\hline
\end{tabular}
tertinggi)

Sempadan mata air : $39 \mathrm{Ha}$

2 Sempadan RTRW Kab Karanganyar waduk 2008-2029, PERMEN PUPR No 28 th 2015 (50 $\mathrm{m}$ dari tepi muka air tertinggi)

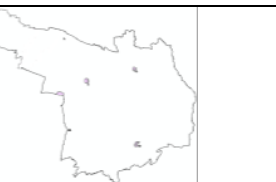

3 Sungai $\quad$ Pedoman RI 38 2011, Permen No 5 2008, PERMEN PUPR No 28 th 2015, RTRW Kab Karanganyar 2008-2029

Kawasan Waduk : $224 \mathrm{Ha}$

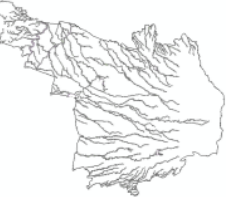

Sempadan Sungai: $5730 \mathrm{Ha}$

$4 \quad$ Hutan $\quad$ PP RI NOMOR 45

Lindung, TAHUN 2004 tentang

Hutan perlindungan hutan,

Produksi, Peraturan Daerah

Kawasan Provinsi Jawa Tengah

Suaka Alam Nomor 6 Tahun 2010

/ Kawasan Tentang Rencana Tata

Pelestarian Ruang Wilayah Provinsi

Alam Jawa Tengah Tahun 2009

- 2029, RTRW

Kabupaten Karanganyar 2008-2029 (30\% dari luas kawasan)

5 Jalan TOL Pedoman S-01-2004 B (Batas terluar dawasja sebesar 20 meter dari as jalan)

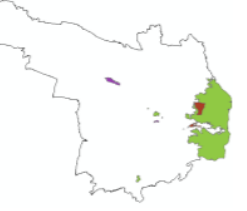

Hutan Lindung : $6766 \mathrm{Ha}$

Hutan Produksi : $145 \mathrm{Ha}$ KSA/KPA : $337 \mathrm{Ha}$

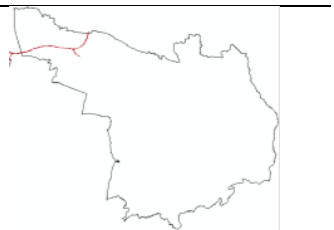

Sempadan Tol : $62 \mathrm{Ha}$

\begin{tabular}{lll}
\hline 6 Jalan Arteri & Pedoman S-01-2004 B \\
& (Batas terluar dawasja \\
& sebesar 20 meter dari as \\
& jalan)
\end{tabular}

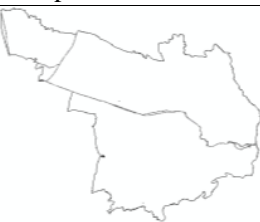

Sempadan jalan Arteri : 365 $\mathrm{Ha}$ 


\begin{tabular}{|c|c|c|c|}
\hline 7 & $\begin{array}{l}\text { Jalan Kereta } \\
\text { Api }\end{array}$ & $\begin{array}{l}\text { Permen No } 52008 \\
\text { (Lebar minimal garis } \\
\text { sempadan kereta api } \\
\text { adalah } 20 \text { meter untuk } \\
\text { jalan kereta api lurus) }\end{array}$ & Sempadan rel $: 42 \mathrm{Ha}$ \\
\hline 8 & $\begin{array}{l}\text { Jaringan } \\
\text { listrik }\end{array}$ & $\begin{array}{l}\text { Permen No } 52008 \\
\text { (Sempadan SUTT 20m, } \\
\text { SUTET 20m, SUTM } \\
2.5 \mathrm{~m}, \text { SUTR } 1.5 \mathrm{~m} \text { ) }\end{array}$ & $\begin{array}{l}\text { Sempadan SUTT, SUTET, } \\
\text { SUTM : } 209 \mathrm{Ha}\end{array}$ \\
\hline 9 & $\begin{array}{l}\text { Kawasan } \\
\text { rawan } \\
\text { Bencana }\end{array}$ & $\begin{array}{l}\text { BPBP Kabupaten } \\
\text { Karanganyar dalam } \\
\text { upaya perlindungan } \\
\text { kawasan rawan bencana } \\
\text { alam }\end{array}$ & $\begin{array}{l}\text { Rawan banjir: } 821 \mathrm{Ha} \\
\text { Rawan longsor : } 2806 \mathrm{Ha}\end{array}$ \\
\hline
\end{tabular}

Sumber : Hasil Analisis, 2018

4. Mengkonversi raster peta jangkauan kedalam format ASCII

Selanjutnya, data jarak masing-masing faktor tersebut dikonversikan kedalam format ASCII melalui toolbox dari LanduseSim 2.3.1 berupa Raster to ASCII. Tujuannya adalah untuk mengkonversi data cell pada raster masing-masing faktor kedealam bentuk text (.txt) dan menghilangkan koordinat raster tersebut. Format ASCII memungkinkan untuk dibaca pada Software LanduseSim.

5. Mempersiapkan peta transisi pertumbuhan lahan terbangun di Kabupaten Karanganyar dengan pendekatan Cellular Automata

Karena data ASCII masih menggunakan sitem ESRI dalam tahapan simulasi pada LanduseSim, dari data ASCII tersebut diubah lagi kedalam format raster (.tif) dengan sistem LanduseSim, namun bedanya dalam raster ini masih belum terdapat nilai nyata. Tahapan membuat peta transisi sebagai berikut:

a. Menkonversi data peta jangkauan (Distance of spatial

Factor) masing-masing faktor menjadi nilai fuzzy.

Masing-masing faktor yang telah diubah kedalam format raster (.tif) akan dianalisis menjadi data raster berbasis bilangan riil, bernilai antara 0 (jarak terjauh) dan 1 (jarak terdekat). Secara keseluruhan nilai fuzzy pada variabel dalam penelitian ini dikategorikan monotically decreasing dikarenakan semakin dekat dengan industri, permukiman, perdagangan dan jasa, fasilitas umum, kawasan pariwisata, jaringan jalan utama, jaringan jalan sekunder, jaringan listrik dan interchange tol semakin mempengaruhi adanya pertumbuhan lahan terbangun. b. Melakukan overlay untuk memperoleh Suitability Maps

Selanjutnya melakukan overlay terhadap peta-peta hasil analisis fuzzy set. Dalam tahap ini akan dilakukan perhitungan melalui pembobotan pada rentang 0-1 dalam bentuk cell raster menggunakan LandusSim 2.3.1. Semakin besar nilai bobot yang dimiliki oleh sebuah faktor, maka semakin besar pula faktor tersebut mempengaruhi perubahan lahan.

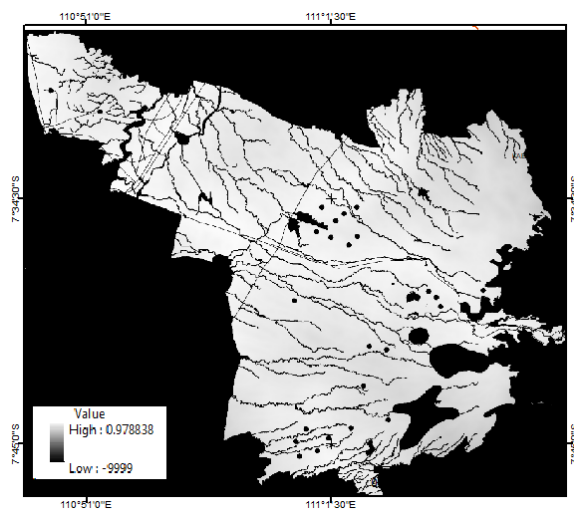

Gambar 7. Transition Potential with Zoning.

Sumber : Hasil Analisis LanduseSim, 2018

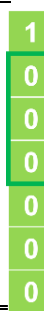

Permisalan : Raster pada layer transisi

Kelas 3

Nilai cell $=\left(\left(1^{*} 0\right)+\left(1^{*} 1\right)+\left(1^{*} 0\right)+\left(1^{*} 0\right)+\left(1^{*} 3\right)+\left(1^{*} 1\right)+\left(1^{*} 0\right)+\left(1^{*} 0\right)+\left(1^{*} 2\right)\right)$

Nilai cell $=7$

Gambar 8. Mekanisme Sum NF 3x3.

Sumber: penulis, 2018

Tabel 8 .

Prediksi Penggunaan Lahan tahun 2038

\begin{tabular}{rllr}
\hline \hline No & Jenis Penggunaan Lahan & Luas (Ha) & Persentase \\
\hline 1 & Sawah & 25701.48 & 32.8 \\
2 & Hl & 6770.97 & 8.6 \\
3 & Hp & 146.25 & 0.2 \\
4 & Ksa/Kpa & 337.05 & 0.4 \\
5 & Perkebunan/Kebun & 6547.23 & 8.3 \\
6 & Sawah Tadah Hujan & 989.73 & 1.3 \\
7 & Semak Belukar & 2863.8 & 3.6 \\
8 & Tegalan/Ladang & 10356.75 & 13.2 \\
9 & Lahan Terbangun & 24151.05 & 30.8 \\
10 & Waduk & 303.3 & 0.4 \\
11 & Sungai & 308.07 & 0.4 \\
& Jumlah & 78475.68 & 100 \\
\hline \hline
\end{tabular}

Sumber: Hasil Simulasi LanduseSim berbasis Cellular Automata, 2018

c. Menentukan Zona Constraint untuk membuat Peta Transisi (Transition Potential with Zoning)

Dari zona yang disibetkan pada Tabel 7 dilakukan overlay dengan data suitability map sebelumnya sehingga diperoleh Transition Potetial Maps dengan zona constraint sebagai berikut, semakin berwarna putih semakin tinggi potensi konversi menjadi lahan terbangun, semakin gelap semakin kecil potensi terkonversi, yang berarti bernilai 0 (Gambar 7).

\section{Membentuk Neighborhood Filter}

Neighborhood filter $(N F)$ merupakan proses perhitungan ketetanggaan yang bekerja pada sistem grid (Pratomoatmojo, 2014). Pada dasarnya sistem ketetanggan/neighborhood yang paling umum digunakan adalah sistem ketetanggana dengan filter $3 \times 3$, pasalnya sistem tersebut mampu mengakomodasi kemampuan berubah pada setiap grid dengan nilai yang paling optimal. Penggunaan filter $3 \times 3$ lebih baik dari pada filter $5 \times 5$ khususnya dalam menghasilkan hubungan dan perubahan cell yang lebih kompak pada setiap kelas penggunaan lahan. 
Tabel 9.

Matrik Perubahan Lahan 2007-2017

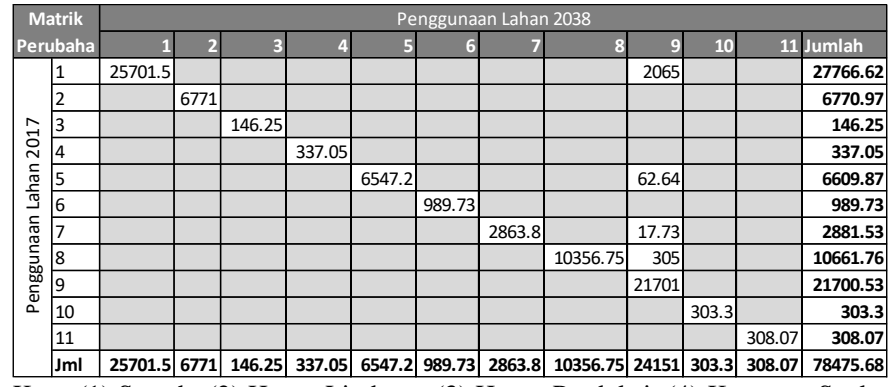

Ket: (1):Sawah, (2):Hutan Lindung, (3):Hutan Produksi, (4):Kawasan Suaka Alam, (5):Perkebunan/kebun, (6):Sawah Tadah Hujan, (7):Semak Belukar, (8):Tegalan/ladang, (9):Lahan Terbangun, (10): Waduk, (11): Sungai Sumber: Hasil intersect GIS, 2018

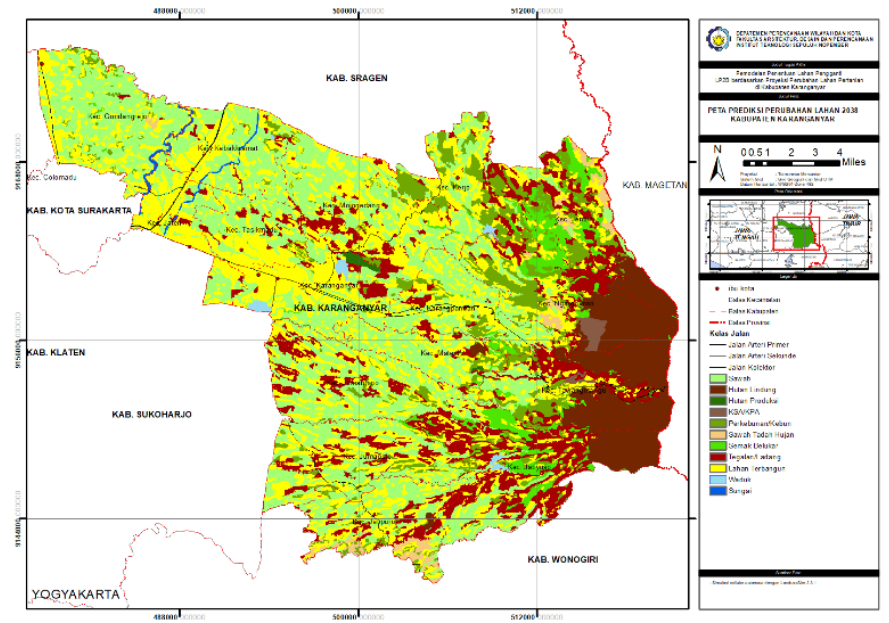

Gambar 9. Prediksi Perubahan lahan 2038.

Penggunaan NF $3 \times 3$ merupakan sistem ketetanggan dengan hasil yang paling akurat dalam urban growth model, dikarenakan kecenderungan NF 3X3 yang lebih memusat dalam mendekati faktor yang mempengaruhi pertumbuhan [21]. Dalam simulasi pada penelitian ini menggunakan NF 3x3 dengan mekanisme operasi $S U M$, dimana merupakan operasi perhitungan dengan mencari nilai total pada perkalian antara bobot NF, Nilai Suitability NF, dan NF Conversion Probability (Gambar 8).

7. Menentukan elastisitas perubahan lahan

Elastisitas perubahan lahan adalah peluang teralih fungsikan suatu lahan menjadi lahan yang menjadi lahan sebagai variabel independen/mempengaruhi. Nilai Elastisitas dalam penelitian ini diasumsikan memiliki nilai yang sama dengan nilai 0 , dalam artian setiap jenis penggunaan lahan memiliki potensi terkonversi lahan terbangun yang sama pula.

8. Menentukan Transition Rules

Mempersiapkan Transition Rules yang terdiri atas beberapa ketentuan sebagai berikut:

a. Jenis landuse yang disimulasikan adalah lahan terbangun tahun 2017

b. $\quad$ Cell Growth $=27228$ cell $/ 2450,504 \mathrm{Ha}$

c. Transition Potential Maps hasil overlay dengan zona constraint

d. Elasticity lahan terbangun $=0$

9. Melakukan simulasi berbasis cellular automata
Tahap terakhir adalah melakukan simulasi perubahan lahan terbangun berbasis Cellular automata pada penggunaan lahan tahun 2017. Hasil dari tahap ini adalah model perubahan lahan tahun 2038 di Kabupaten Karanganyar (Tabel 8 dan 9).

Berdasarkan hasil simulasi diproyeksikan hingga tahun 2038 akan terjadi alih fungsi lahan pertanian seluas $2369.69 \mathrm{Ha}$, yang terdiri dari alih fungsi lahan sawah, sawah tadah hujan dan tegalan/ladang. Pola perubahan cenderung terjadi pada kawasan perkotaan Kabupaten Karanyar (Gambar 9).

\section{Validasi Model Perubahan Lahan}

Teknik validasi yang digunakan dalam hasil pemodelan adalah metode Event Validity. Event Validity adalah teknik validasi dengan melakukan perbandingan dengan system yang telah ada dilapangan. Validasi model lahan terbangun dilakukan dengan melakukan perbandingan peta penggunaan lahan eksisting tahun 2017 dengan peta hasil simulasi tahun 2007 yang diproyeksikan ke tahun 2017. Dilakukan reduksi variabel interchange Tol yang digunakan dalam simulasi. Dikarenakan pada tahun 2007 belum terdapat pengaruh pintu tol. Adapun transition rules pada model validasi sebagai berikut:

a. Jenis landuse yang disimulasikan adalah lahan terbangun tahun 2007

b. Cell Growth $=16944$ cell $/ 1524.99 \mathrm{Ha}$

c. Transition Potential Maps hasil overlay dengan zona constraint

d. Elasticity lahan terbangun $=0$

Dari hasil simulasi diperoleh kecocokan data dengan tahun 2017 eksisting sebesar $98.71 \%$, sehingga memiliki akurasi yang cukup baik untuk dijadikan model prediksi pertumbuhan lahan

\section{KESIMPULAN}

1. Perubahan lahan yang terjadi pada tahun 2007-2017 di Kabupaten Karanganyar dipengaruhi oleh pertumbuhan lahan terbangun seluas $1524.99 \mathrm{Ha}$, dan paling signifikan cenderung mengkonversi lahan pertanian

2. Faktor yang mempengaruhi pertumbuhan lahan terbangun di Kabupaten Karanganyar terdiri dari variabel kedekatan dengan industri, permukiman, perdangangan dan jasa, pariwisata, fasilitas umum, jalan tol, jaringan jalan utama, jaringan jalan sekunder dan jaringan jalan listrik

3. Kebutuhan lahan terbangun hingga tahun 2038 berdasarkan perhitungan melalui target pada RTRW Kabupaten Karanganyar sebesar $2450.504 \mathrm{Ha}$.

4. Hasil prediksi pada tahun 2038 terjadi perubahan lahan pertanian seluas $2369.69 \mathrm{Ha}$. dengan pola pertumbuhan cenderung kearah perkotaan Kabupaten Karanganyar

5. Validasi model dilakukan melalui metode Event Validity dengan melakukan simulasi dari tahun 2007 ke 2017 yang dibandingkan dengan penggunaan lahan eksisting tahun 2017. Hasil tingkat akurasi komparasi $98.71 \%$

6. Kelebihan penggunaan model pertumbuhan lahan terbangun dalam upaya prediksi perubahan lahan pertanian dengan Software LanduseSim berbasis Cellular Automata adalah mampu meminimalisir akan dampak dari intervensi alih fungsi lahan pertanian pada masa yang akan datang, sehingga bisa diterapkan pada prediksi alokasi potensi 
LP2B (Lahan Pertanian Pangan Berkelanjutan) yang secara regulasi tidak boleh teralih fungsikan.

\section{DAFTAR PUSTAKA}

[1] S. Hastuty, "Identifikasi Faktor Pendorong Alih Fungsi Lahan Pertanian," J. UNCP, 2017.

[2] [BPS] Badan Pusat Statistika, "Kabupaten Karanganyar dalam Angka," Karanganyar, 2017.

[3] A. Prasetyo, "Faktor-Faktor yang Mempengaruhi Alih Fungsi Lahan Pertanian ke Sektor Non Pertanian di Kabupaten Karanganayar," Surakarta, 2012.

[4] P. Astuti, "Pengaruh Perkembangan Kota Surakarta terhadap Permukiman di Kawasan Solobaru," Surakarta, 2008.

[5] J. Sartohadi, "Evaluasi Potensi Degradasi Lahan dengan Menggunakan Analisa Kemampuan Lahan dan Tekanan Penduduk Terhadap Lahan Pertanian di Kecamatan Kokap Kabupaten Kulon Progo," Yogyakarta, 2008.

[6] N. A. Pratomoatmojo, "Land Use Change Modelling Under Tidal Flood Scenario by Means of Markov Cellular Automata in Pekalongan Municipal," Universitas Gadjah Mada, 2012.

[7] Kementrian Agraria, "UU no 41 tahun 2009 tentang Perlindungan Lahan Pertanian Pangan Berkelanjutan," 2009.

[8] S. Rozani Nasution, Teknik Sampling. Sumatera Utara: USU Digital Library, 2003.

[9] T. Saaty, The Analytic Hierarchy Process. New York: Mc Graw Hill, 1980.

[10] G. Daniel, Modeling Land Use And Land Cover Change. USA, 2004.
[11] M. Batty, "Modeling Urban dynamic through GIS-based cellular automata," J. Comput. Environtment Urban Syst., vol. 3, no. 23, pp. 205-233, 1999.

[12] A. Wahyudi and U. Lui, "Cellular Automata for Urban Growth Modelling:: A Review on Factors defining Transition Rules," Int. Rev. Spat. Plan. Sustain. Dev., vol. 4, no. 2, pp. 60-75, 2016.

[13] N. Pratomoatmojo, "LanduseSim sebagai aplikasi pemodelan dan simulasi spasial," in Seminar Nasional Cities: Eco City Utopis or realistis?, 2014.

[14] I. M.Baihaqi, "Aspek Perpetakan untuk penyusunan rencana detail tata ruang (RDTR)," Bogor, 2012.

[15] E. Croxton and D.J. Crowden, Appiled General Statistics. New York: Prentice Hal, Inc, 1955.

[16] G. Bramley, "Key Driving Factors Influencing Urban Growth: Spatial-Statistical Modelling with CLUE-s," in Environmental Problems and Governance, 2014, pp. 123-145.

[17] R. Saefulhakim, "Kebijaksanaan Pengendalian Konversi Sawah Beririgrasi Teknik Prosiding Pertemuan Pembahasan dan Komunikasi Hasil Penelitian Tanah dan Agriklimat,” Bogor, 1995.

[18] L. Nasoetion, "Masalah Alih Fungsi Lahan Pertanian dan Dampaknya terhadap Keberlangsungan Swasembada Pangan," Bogor, 1996.

[19] G. Rahardian, "Skenario Perkembangan Permukiman di Kawasan Perkotaan Bandar Kedungmulyo pasca terbangunnya interchange jalan Tol Mojokerto-Kertosono," Surabaya, 2015.

[20] H. Simanjuntak, "Calculation Methods of Topographic Factors Modification Using Data Digital Elevation Model (DEM) To Predict Erosion)," Media Konserv., vol. 22, no. 3, pp. 242-251, 2017.

[21] C. Amujal, "Using Cellular Automata to Analyze and Model Urban Growth,” Copenhagen, 2015. 